\title{
Quality of School Life in Primary School: Students' Perception
}

\author{
Marija Buterin Mičić
}

University of Zadar, Department of Pedagogy, Obala kralja Petra Krešimira IV. 2, HR-23000, Zadar, Croatia, mbuterin2@gmail.com

\begin{abstract}
The paper deals with research data on quality of school life perceived by fifth- to eighth-grade primary school students. The data were collected by questionnaire survey. Students' overall satisfaction with school and perception of specific dimensions of school life are analysed as well as differences of their assessments regarding gender, grade and school achievement. On the ground of research results, the importance of the enhancement of the quality of school life is emphasised.
\end{abstract}

Keywords: school life, students' perception, primary school, quality.

\section{Introduction}

The importance of the affirmation of a humanistic oriented paradigm based on the maxim slower, less, better, nicer (Glauber, 2006) is relevant to considering numerous challenges of modern life. According to Rifkin (2006), it is about a culture of empathy and caring which implies the abandonment of the politics of power and the primacy of economic interest. In prosperous societies, an ever-greater emphasis is being placed on the non-economic aspects of human existence, such as the need for self-fulfilment and the importance of affective experiences and positive emotions. This is supported by data on how happy individuals are more socially active, are more interested in other people, work better, live longer and display socially desirable behaviour (Diener, 2000).

The quality of education is usually associated with success, efficiency, and high qualifications, while the satisfaction that arises from the learning process itself, the sharing of experiences, sense of successes, and other positive aspects of school life are often 
disregarded (Vojtová, 2008). The institution of school shouldn't be perceived only as a place of teaching and acquiring knowledge, but also as a place of well-being since the social and emotional dimension of school life represents the source from which students' basic needs are satisfied (such as a sense of success, community involvement, etc.). The concept of pedagogical well-being is related to the pedagogy of positive emotional experiences, encouragement of holistic human development, and support of the learning process (Meriläinen, Lappalainen and Kuittinen, 2008). According to Pietarinen, Soini and Pyhältö (2008), school well-being is the foundation of meaningful learning, which results in changes in the lives of individuals that, in turn, help create their well-being. Many authors have attempted to define which aspects of schooling play an important role in students' well-being by evaluating not only the general quality of life in school, but its specific areas as well. According to Karatzias, Power, Flemming, Lennan and Swanson (2002), these factors are related to the school environment, educational experiences, and inclusion into school life.

Students' attitudes towards school represent a subject of research interest as students spend a significant part of their time at school. Therefore, the experiences gained during this period are an important part of their lives and it is considered they affect the learning process and thus school success. According to Ainley, Goldman and Reed (1990), assessment of students' perceptions of quality of school life has to be considered as a prerequisite for enhancement of the quality of school education.

This research problem stems from theoretical considerations and empirical studies of quality of life at a general level and its implications. In this sense, the quality of life is more closely investigated at a general level on adult respondents, while research on quality of school life are relatively rare (Epstein and McPartland, 1976). Quality of school life as a pedagogically relevant research problem can be considered within the broader research field by recognition of the importance of students' social and emotional development.

Epstein and McPartland (1976) are authors of one of the first measures of quality of school life. According to authors, this measure is founded on several dimensions of the students' reactions - their general attitudes toward school, their relationship with their teachers, and their commitment to school work. Attempts were made to expand this model in order to include more specific dimensions of school life. According to the Williams and Batten's model (1981, as cited in Pang, 1999a), students' assessments of quality of life in school refer to their general well-being and feelings regarding specific dimensions of school life (a sense of success in schoolwork, teacher-student relations, importance of schooling, pupils' relations with classmates and other people, self-motivation in learning and a sense that learning is enjoyable). Ainley and Bourke (1992, as cited in Leonard, 2002) also differentiate general perception of quality of life in school, i.e. a general satisfaction with school and perception of its specific dimensions - perception of the quality of relationship between students and teachers, students and other people in school, the perception of the importance of schooling for the future life, the sense of 
achievement in school work and the sense of motivation for learning. Building upon this model, Leonard (2002) defines quality of life in school as experiences attained in school and other feelings related to specific aspects of school life.

One of the first large studies of the quality of school life was carried out by Epstein and McPartland (1976) on a sample of students between the ages of 10 and 18. Their research affirmed the significance of emotional experience in the development of motivation for learning, i.e. students who were happy at school expressed more positive attitudes toward other parts of school life, behaved and performed better at school. Linnakylä and Brunell (1996) found out that school life has impact on the students' personal and social identity formation. Also, they found out that school life experiences have an important role in their learning process, attitudes toward life-long learning and education in the future. According to Booth and Ainscow (2002), students' attitudes toward school life affect their approach to learning and education. Raboteg-Šarić, Šakić and Brajša-Žganec (2009) examined the relation of the quality of school life, motivation, inappropriate behaviour in school and academic achievement of fifth- to eighth-grade primary school students. They ascertained that students' less negative feelings toward school and stronger sense of school competence are significant predictors of their academic success. A stronger sense of school competence of students was also found to be significant predictor of misbehaviour reduction. Also, they found that students' perception of relevance of schooling in the future was significant predictor of goals orientation. The results of empirical research have also shown that perception of the quality of life in school is related to gender and age, parents' level of education (Mok and Flynn, 1997; Marks, 1998), absenteeism in primary schools (Leonard, Bourke and Schofield, 2000), classroom learning, i.e. teacher's support in learning, positive and active learning experiences (Kong, 2008), motivation (UNESCO, 2005), academic performance and behaviour (Malin and Linnakylä, 2001), school self-esteem (Karatzias, Power, Flemming, Lennan and Swanson, 2002), responsibility for school successes and failures (Wolf, Chandler and Spies, 1981) and school type, i.e. private and public primary school (Aliyev and Tunc, 2015).

There are limited studies on perception of the quality of school life in Croatia (Raboteg-Šarić and Šakić, 2007; Raboteg-Šarić, Šakić and Brajša-Žganec, 2009; Hanzec, Kovačević and Brajša-Žganec, 2016). With aim to its better understanding and improvement, the students' perception of the quality of school life as a research problem has been identified. The goal of this research is to explore quality of school life perceived by primary school students as well as differences of their assessments regarding gender, grade and school achievement.

The objectives of the research are as follows:

- to examine how students experience the quality of school life;

- to examine whether there are significant differences in the quality of school life assessments regarding students' gender, grade level and school achievement. 
The aforementioned research objectives are chosen based on the thesis that the promotion of the quality of school life is based on the insight of the students' assessment of satisfaction with the school as well as specific areas of school life. Furthermore, they are based on the assumption that there are differences in pupils' assessment of the quality of school life regarding selected characteristics (gender, age and school success).

\section{Methodology}

\section{Participants and the procedure}

A total of 433 fifth through eighth grade primary school students from six elementary schools in Zagreb, Rijeka and Zadar (Croatia) participated in the study. Namely, 203 boys and 230 girls participated in the study, 100 of them attended fifth, 118 sixth, 103 seventh and 112 eighth grade. An anonymous questionnaire survey was conducted at the end of the school year 2014/2015. It was conducted during regular classes after the research participants were informed about the purpose of the research and completion of the questionnaire survey. Depending on the students' age, the completion lasted approximately $15-20$ minutes.

\section{Instrument}

Data were collected using the questionnaire survey. In addition to the questions about the gender, grade level and school achievement at the end of the previous school year, the instrument included a version of Quality of School Life Questionnaire- QSLQ (Ainley and Bourke, 1992; as cited in Leonard, 2002), which was adapted for use in primary schools in Croatia by Raboteg-Šarić, Šakić and Brajša-Žganec (2009). All items begin with the words, "My school is a place where..." The adapted version consists of six scales:

- general satisfaction with the school - refers to the students' general positive attitude, i.e. their feelings towards school (6 items, e.g. ...I really like to go each day)

- learning experience - examines students' perception of their own learning experience at school as a challenging and enjoyable process, i.e. the extent to which students enjoy and feel motivated for learning at school (5 items, e.g. ...learning is fun)

- $\quad$ sense of school competence - examines the students' perception of one's own school competence, i.e. experience of success and achievement in school work (5 items, e.g. ...I am a successful as a student)

- relevance of schooling - refers to the students' perception of the relevance of the education gained at school, i.e. the students' assessment about role of the school in their preparation for life in the future (6 items, e.g. ...the things I learn are important to me) 
- the quality of the relationship with the teachers - examines the students' perception of the quality of teacher relations toward the students (4 items, e.g. my teachers are fair to $\mathrm{me}$ )

- social integration of students in school - assesses the quality of student relations with students and other people in school (8 items, e. g. ...other students accept me as $(\mathrm{am})$.

The students responded by choosing one response on the five-point Likert scale (where 1 meant I don't agree at all, and 5 - I completely agree). Two factor analyses were carried out for the items on students' general feelings toward school and for the items on students' attitudes regarding the specific dimensions of school life. The first factor analysis resulted in one significant factor and explains $66 \%$ of the common variance. The second factor analysis of the five subscales also explains $66 \%$ of the total variance.

Table 1

Factor loadings of General satisfaction with the school scale

\begin{tabular}{lc}
\hline Items & Factor loadings \\
\hline Item 1 & 0.86 \\
Item 2 & 0.86 \\
Item 3 & 0.80 \\
Item 4 & 0.73 \\
Item 5 & 0.63 \\
Item 6 & 0.84 \\
\hline
\end{tabular}

Table 2

Factors and factor loadings of specific subscales items of QSLQ

\begin{tabular}{|c|c|c|c|c|c|c|c|c|c|}
\hline \multicolumn{2}{|c|}{$\begin{array}{c}\text { Factor } 1 \\
\text { Sense of school } \\
\text { competence }\end{array}$} & \multicolumn{2}{|c|}{$\begin{array}{c}\text { Factor } 2 \\
\text { Relevance of } \\
\text { schooling }\end{array}$} & \multicolumn{2}{|c|}{$\begin{array}{c}\text { Factor } 3 \\
\text { Learning } \\
\text { experience }\end{array}$} & \multicolumn{2}{|c|}{$\begin{array}{c}\text { Factor } 4 \\
\text { Relationship } \\
\text { with the teachers }\end{array}$} & \multicolumn{2}{|c|}{$\begin{array}{c}\text { Factor } 5 \\
\text { Social } \\
\text { integration }\end{array}$} \\
\hline Item 1 & 0.81 & Item 1 & 0.77 & Item 1 & 0.69 & Item 1 & 0.66 & Item 1 & 0.75 \\
\hline Item 2 & 0.76 & Item 2 & 0.71 & Item 2 & 0.75 & Item 2 & 0.69 & Item 2 & 0.71 \\
\hline Item 3 & 0.78 & Item 3 & 0.74 & Item 3 & 0.75 & Item 3 & 0.61 & Item 3 & 0.62 \\
\hline Item 4 & 0.51 & Item 4 & 0.69 & Item 4 & 0.75 & Item 4 & 0.60 & Item 4 & 0.48 \\
\hline \multirow[t]{4}{*}{ Item 5} & 0.77 & Item 5 & 0.72 & Item 5 & 0.76 & & & Item 5 & 0.58 \\
\hline & & Item 6 & 0.83 & & & & & Item 6 & 0.79 \\
\hline & & & & & & & & Item 7 & 0.48 \\
\hline & & & & & & & & Item 8 & 0.72 \\
\hline
\end{tabular}


The results of the internal consistency analysis indicate satisfactory reliability for all scales (general satisfaction $\alpha=.90$, sense of school competence $\alpha=.89$, relevance of schooling $\alpha=.92$, learning experience $\alpha=.89$, relationship with the teachers $\alpha=.86$ and social integration $\alpha=.85$ ).

\section{Findings}

The first research task was to explore and analyse the extent to which students were satisfied with the school as a whole and how they perceived the specific areas of school life. Descriptive statistics were used to accomplish this research task. The results of this analysis are shown in Table 3.

Table 3

Students' Perception of Quality of School Life

\begin{tabular}{lcc}
\hline \multicolumn{1}{c}{ Scales } & $M$ & $S D$ \\
\hline General satisfaction & 3.22 & 1.01 \\
\hline Sense of school competence & 3.91 & 0.81 \\
\hline Relevance of schooling & 4.08 & 0.87 \\
\hline Learning experience & 3.01 & 1.01 \\
\hline Relationship with the teachers & 3.59 & 1.00 \\
Social integration & 3.85 & 0.73 \\
\hline
\end{tabular}

Analysing the results of students' general satisfaction with the school, it can be seen that the mean score is located near the middle of the scale $(M=3.22)$. This means that students express neutral feelings towards school. Analysing the results of students' self-assessment of school competence, it was found that calculated value of arithmetic mean is 3.91, meaning that students perceive themselves quite successful in school work. Furthermore, calculated arithmetic mean for the subscale relevance of schooling $(M=4.08)$ indicate that students believe education plays an important role in their future life.

Analysing the results of students' perception of their own learning experience at school as a challenging and enjoyable process, it can be seen that they express divided attitudes as the mean score is located in the middle of the scale $(M=3.01)$.The results also indicate that students are not fully satisfied with the quality of the teacher-student relationships the calculated value of arithmetic mean is 3.59. Analysing the results of students' perception of the quality of social life in school, it can be seen that they are quite satisfied and perceive school as a place where students generally get along and accept each other $(M=3.85)$. 
Table 4

Students' perception of Quality of school life and gender

\begin{tabular}{lccccc}
\hline \multicolumn{1}{c}{ Scales } & \multicolumn{2}{c}{ Boys } & \multicolumn{2}{c}{ Girls } & \multirow{2}{*}{$F$} \\
& $M$ & $S D$ & $M$ & $S D$ & \\
\hline General satisfaction & 3.15 & 1.01 & 3.28 & 1.01 & 1.63 \\
\hline Sense of school competence & 3.82 & 0.84 & 3.98 & 0.78 & $3.90^{*}$ \\
\hline Relevance of schooling & 4.06 & 0,90 & 4.09 & 0,85 & 0.09 \\
\hline Learning experience & 3.01 & 1.01 & 2.98 & 1.07 & 0.15 \\
Relationship with the teachers & 3.54 & 1.01 & 3.64 & 0.98 & 1.07 \\
\hline Social integration & 3.80 & 0.78 & 3.89 & 0.68 & 1.64 \\
\hline${ }^{*} \mathrm{p}<.05$ & & & & &
\end{tabular}

The part of second research task was to investigate and analyse whether there are significant differences in the quality of school life assessments regarding students' gender.

Table 4 lists the values of arithmetic means and standard deviations for students' assessment on all scales, as well as the results of analysis of variance regarding gender. The statistically significant difference was found on one scale - sense of school competence. The results of the ANOVA showed that the $F$ value was 3.90 (at 5\% significance level). It was found that girls feel more successful $(M=3.98)$ than boys $(M=3.82)$ in school activities. However, mean values indicate that this difference isn't large, and that students generally consider themselves quite successful.

On the other hand, there was no statistically significant difference between boys and girls in the overall satisfaction with the school and their perception of other specific dimensions of school life. Based on insights into values of arithmetic means, it can be seen that both girls and boys express similar, neutral attitudes and feelings towards school $\left(M_{\text {boys }}=3.15 ; M_{\text {girls }}=3.28\right)$, and perceive learning at school as insufficiently interesting and challenging $\left(M_{\text {boys }}=3.01 ; M_{\text {girls }}=2.98\right)$. Furthermore, both groups are relatively satisfied with the quality of the teacher-students relationship $\left(M_{\text {boys }}=3.54 ; M_{\text {girls }}=3.64\right)$, they feel integrated into the social life of school $\left(M_{\text {boys }}=3.80 ; M_{\text {girls }}=3.89\right)$ and generally attach importance to the role of the school in their preparation for the future life $\left(M_{\text {boys }}=4.06\right.$; $M_{\text {girls }}=4.09$ ).

Another part of the second research task was to explore and analyse whether the students' perception of quality of school life significantly differs regarding grade level. As it can be seen in Table 5, analysing the results of ANOVA, there were statistically significant differences in general satisfaction with the school among younger (fifth and sixth grade) and older students (seventh and eighth grade). The $F$ value is -3.10 at $1 \%$ significance level. Namely, older students are less satisfied with the school $(M=3.07)$ than younger students $(M=3.37)$. The values of the arithmetic means indicate that these differences aren't large and that both groups express neutral attitudes. 
Table 5

Students' perception of Quality of school life and grade

\begin{tabular}{lccccc}
\hline \multirow{2}{*}{ Scales } & 5th \& 6 th grade & 7th \& 8th grade & \multirow{2}{*}{} \\
& $M$ & $S D$ & $M$ & $S D$ & \\
\hline General satisfaction & 3.37 & 1.02 & 3.07 & 0.98 & $-3.10^{* *}$ \\
\hline Sense of school competence & 4.04 & 0.77 & 3.77 & 0.83 & $-3.58^{\star *}$ \\
\hline Relevance of schooling & 4.33 & 0,78 & 3.82 & 0,89 & $-6.39^{* *}$ \\
\hline Learning experience & 3.21 & 1.06 & 2.77 & 0.97 & $-4.56^{* *}$ \\
\hline Relationship with the teachers & 3.77 & 0.98 & 3.40 & 0.98 & $-3.91^{* *}$ \\
\hline Social integration & 3.95 & 0.76 & 3.75 & 0.76 & $-2.83^{* *}$ \\
\hline
\end{tabular}

${ }^{*} \mathrm{p}<.05 ;{ }^{* *} \mathrm{p}<.01$

The results of ANOVA showed that there were statistically significant differences in perceptions of learning experience regarding students' grade $(F=-4.56 ; \mathrm{p}<.01)$. Namely, older students perceive learning in the school as less challenging and interesting $(M=2.77)$ than younger students $(M=3.21)$, although the values of the arithmetic means indicate that both groups express neutral attitudes.

Furthermore, there were statistically significant differences in students' perception of the relevance of schooling $(F=-6.39 ; \mathrm{p}<.01)$ and their sense of school competence $(F=-3.58 ; \mathrm{p}<.01)$. Namely, older students perceive the role of the school in their future life as less important $\left(M_{\text {older }}=3.82 ; M_{\text {younger }}=4.33\right)$ and perceive themselves as less competent in what they do in school $\left(M_{\text {older }}=3.77 ; M_{\text {younger }}=4.77\right)$. However, both groups have given predominantly positive estimates.

The results of ANOVA showed that there were statistically significant differences in the quality of teachers' relationship with students $(F=-3.91 ; \mathrm{p}<.01)$ and the quality of students' relations with students and other people in school $(F=-2.83 ; \mathrm{p}<.01)$ regarding students' grade. Namely, seventh and eighth grade students disadvantageously evaluate the quality of teachers' relationship with students $\left(M_{\text {older }}=3.40 ; M_{\text {younger }}=3.77\right)$ as well as the quality of students' relations with other students and other people in school $\left(M_{\text {older }}=3.75 ; M_{\text {younger }}=3.95\right)$.

The last part of second research task was to investigate and analyse whether the students' perception of quality of school life significantly differs regarding their school achievement. The ANOVA was used to accomplish this research task. As it can be seen in Table 5, there was a statistically significant difference in overall school satisfaction $(F=6.42 ; \mathrm{p}<.01)$ and satisfaction with the specific dimensions of school life $\left(F_{\text {competence }}=6.21\right.$; $\left.F_{\text {relevance }}=9.16 ; F_{\text {learning }}=5.29 ; F_{\text {teachers }}=11.25 ; F_{\text {social integration }}=16.10 ; \mathrm{p}<.01\right)$. The results of further analysis of the obtained results (Scheffé test) showed that students with excellent school achievement, compared with students with very good school achievement, are more satisfied with school $\left(M_{\text {excellent }}=3.39 ; M_{\text {very good }}=3.03\right)$ and perceive learning in school as more interesting and challenging $\left(M_{\text {excellent }}=3.14 ; M_{\text {very good }}=2.80\right)$, although the difference isn't 
large and both groups express neutral attitudes. Furthermore, students with excellent school achievement, compared with students with very good school achievement, consider that the school has a greater role in their preparation for the future life $\left(M_{\text {excellent }}=3.14\right.$; $M_{\text {very good }}=2.80$ ) with the remark that the both groups mainly express positive estimates. Furthermore, it was found that students who feel more competent in school work also have higher school achievement $\left(M_{\text {good and less }}=3.22 ; M_{\text {very good }}=3.66 ; M_{\text {excellent }}=4.28\right)$.

Table 6

Students' perception of quality of school life and school achievement

\begin{tabular}{|c|c|c|c|c|c|c|c|c|}
\hline \multirow{2}{*}{ Scales } & \multicolumn{2}{|c|}{$\leq \operatorname{good}$} & \multicolumn{2}{|c|}{ very good } & \multicolumn{2}{|c|}{ excellent } & \multirow{2}{*}{$F$} & \multirow{2}{*}{ Scheffé test results } \\
\hline & $M$ & $S D$ & $M$ & $S D$ & $M$ & $S D$ & & \\
\hline General satisfaction & 3.15 & 0.99 & 3.03 & 1.01 & 3.39 & 0.99 & $6.42^{\star *}$ & very good $<$ excellent $^{* *}$ \\
\hline $\begin{array}{l}\text { Sense of school } \\
\text { competence }\end{array}$ & 3.22 & 0.90 & 3.66 & 0.71 & 4.28 & 0.67 & $6.31^{\star *}$ & $\begin{array}{l}\leq \text { good }<\text { very good }^{* *} \\
\leq \text { good }<\text { excellent }^{* *} \\
\text { very good }<\text { excellent }^{* *}\end{array}$ \\
\hline $\begin{array}{l}\text { Relevance of } \\
\text { schooling }\end{array}$ & 4.07 & 0.91 & 3.87 & 0.92 & 4.25 & 0.79 & $9.16^{\star \star}$ & very good $<$ excellent $^{* *}$ \\
\hline Learning experience & 3.02 & 1.08 & 2.80 & 1.00 & 3.14 & 1.04 & $5.29^{* *}$ & very good $<$ excellent $^{* *}$ \\
\hline $\begin{array}{l}\text { Relationship with } \\
\text { the teachers }\end{array}$ & 3.72 & 0.92 & 3.31 & 1.04 & 3.78 & 0.93 & $11.25^{\star *}$ & 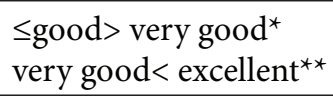 \\
\hline Social integration & 3.72 & 0.69 & 3.65 & 0.77 & 4.05 & 0.66 & $16.10^{* *}$ & $\begin{array}{l}\leq \text { good }<\text { excellent }^{* *} \\
\text { very good }<\text { excellent }^{* *}\end{array}$ \\
\hline
\end{tabular}

Furthermore, the results of Scheffé test showed that students with excellent school achievement are more satisfied with the quality of their social integration in school $(M=4.05)$ compared to students with lower school achievement $\left(M_{\text {good and less }}=3.72\right.$; $\left.M_{\text {very good }}=3.65\right)$. Also, the results indicate that they are more satisfied with the quality of the relationship between teachers and students $(M=3.78)$ compared to students with very good school achievement $(M=3.31)$. At the same time, students with very good school achievement are less satisfied with the quality of the relationship between teachers and students $(M=3.31)$ than students with lower school achievement $(M=3.72)$.

\section{Discussion}

\section{Quality of school life}

The results of this study indicate that students mainly express neutral feelings towards school, which indicates that spending time in school isn't especially pleasurable to them. Their neutral attitudes can be explained through Schofield and Bourke's opinion 
(1997, as cited in Leonard, Bourke and Schofield, 1999) that the time students spend in school can be a source of stress, considering that scholastic success is the main determinant of their academic path and profession in future.

The results of this research also indicate that students mainly view schooling as an opportunity to learn what is necessary for their future. In general, students think that what they learn is useful and important and that school prepares them well for the future. Such results can be interpreted by a generally accepted view of school education as a factor that has a key role in the individual's further educational and professional path. They also perceive school as a place where they can develop their competences and they are mostly sure of their ability to attain better learning results. Social integration in the school environment is considered positive, as they perceive school as a place of positive social support. The results show that learning in school is not particularly enjoyable. In addition, students are not entirely satisfied with the quality of the relationship between teachers and students.

The results of this empirical research, supported by other researchers which highlights the importance of students' perception of quality of life in school have important implications for practice and for future research on the quality of school life. Innovative curriculum approaches should be employed by offering individualized programs that engage students in life-relevant activities that also derive from their interests and needs. As Kaffemaniené, Masiliauskiené, Melienè and Miltenienè (2017) emphasize, the modernity of school implies pupils' active and independent learning, teaching and learning which are facilitated by modern technology and oriented toward humanistic values, respect for individuality, democratic principles etc. As such, they can contribute to empowering students' motivation for learning, i.e. their perception of learning in school as a process that is worth the effort, that is challenging enough, interesting and relevant, and in which they actively engage. It should be kept in mind that students are aware of the importance of schooling and its role in their further educational and professional path, which is closely connected to the quality of life. This perception of school represents a source of stress arising from the need to attain high achievement on tests. These stressors represent a threat to students' well-being, which undoubtedly affects their learning, and thus their scholastic success. Teachers should be aware of the negative effects of these interactions in order to actively participate in creating a positive school environment, thus contributing to the well-being of students. Teachers also should expand their role in their relationship with students and act not only as an expert in their subject area, but as pedagogues whose actions contribute to the strengthening of students' well-being, help them face failures and stresses, and encourage them to gain, share and self-reflect positive experiences in school. Furthermore, special attention should be given to the learning process itself, which students often perceive as insufficiently interesting and stimulating. Teachers should thus enable students to take control of their own learning process. This means that teachers should ensure space for independent research, encourage 
students to show what they have learned or done independently, to encourage a culture of asking questions and making suggestions, and to encourage social forms of work that enable the exchange of ideas. In other words, students should be enabled to contribute through their ideas, suggestions, and active involvement. Future research should focus on the relation of quality of school life and other school variables (such as the effects of individualized school programs that engage students in life-relevant activities, students' learning autonomy and well-being support).

\section{Quality of school life regarding gender, grade and school achievement}

The results of the analysis of variance regarding gender indicate that the statistically significant difference was found only on sense of school competence subscale in favour of female students. Prior research has also shown gender-based differences in the sense of school competence in favour of girls (Marks, 1998; Raboteg-Šarić, Šakić and BrajšaŽganec, 2009). The results can be reviewed through Hartley and Sutton's (2013) explanation according to which girls are considered to be academically superior in terms of capability, execution, motivation and self-regulation. According to Pomerantz, Altermatt and Saxon (2002), girls, compared to boys, make a greater effort to satisfy the demands of adults. This explanation can be applied in the school context and also related to their greater dedication and effort in performing school obligations, as well as a greater need for affirmation of their successes too.

The results of ANOVA indicate that there were statistically significant differences in general satisfaction with the school and in perceptions of all dimensions of school life among younger and older students and students with different school achievement. The obtained results are in accordance with the findings of the previous researches (Epstein and McPartland, 1976; Gil, 1996; Henderson and Fisher, 2008; Kong, 2008; Raboteg-Šarić, Šakić andBrajša-Žganec, 2009; Pang, 1999b). In accordance with Vojtova’s (2008) findings, it is alarming to note that students' satisfaction with school decreases as they age. The insufficient satisfaction of older students with the quality of school life can be explained by the fact that teachers in higher classes pay less individual attention to students (Okun, Walton Braver and Weir, 1990). According to Epstein and McPartland (1974) one potential cause of this trend is the fact that schools are less and less capable of satisfying the diverse interests, needs, and capabilities of their students, which become more complex and diverse as they are getting older.

The results of post hoc analysis showed that students with excellent school achievement, compared with students with very good school achievement, are more satisfied with the school, consider that the school has a greater role in their preparation for the future life and perceive learning in school as more interesting and challenging. Furthermore, it was found that students who are more satisfied with the quality of their social integration in school and feel more competent in school work also have higher school achievement. Also, results indicate that students with excellent school achievement are more satisfied 
with the quality of the relationship between teachers and students compared to students with very good school achievement. At the same time, students with very good school achievement are less satisfied with the quality of the relationship between teachers and students than students with lower school achievement. The obtained results are in accordance with the findings of the research carried out by Henderson and Fisher (2008) on the connection between students' perceptions of the relationship between teachers and students and perceptions of their own success. These results affirm that this connection plays an important role in students' school success, emphasising the importance of maintaining friendly relationships and the feeling of freedom in schoolwork, both of which increase students' motivation to learn.

The obtained results must be examined with reservations, as there is a difference in the number of students within particular categories (students with good and lower school achievement being placed into a single category). The results of this empirical research, supported by other researchers about the role of gender, grade and school achievement on students' perception of quality of life in school, have important implications for future research on the quality of school life and for practice. Such research should investigate the effect of some school related variables (such as academic motivation, school work dedication, practice of individual approach to every student, sense of school community, etc.) on quality of school life and vice versa. Results of this research on differences in perception of quality of school life regarding gender, grade and school achievement also have important implications for practice. Teaching practice and school climate should be developed to support all students in terms of rising the quality of life in school with special emphasis on their overall satisfaction with school, student-teacher relationship and learning experience at school. As it is confirmed in this study that there are difference in students' overall satisfaction with their school regarding grade and school achievement, special emphasis should be made regarding older students, students with lower school achievement and sense of school competence among male students. Differences in perception of specific dimensions of school life regarding grade and school achievement were also observed while the results of analysis of variance regarding gender indicate that the statistically significant difference was found only on sense of school competence subscale.

\section{Conclusion}

The aim of this empirical study was to explore the quality of school life perceived by primary school students as well as differences of their assessments regarding gender, grade and school achievement. This research stems from the assumption that the quality of education should not be assessed solely in terms of students' academic achievement, but it should include non-academic dimension of schooling such as students' perception of quality of their school life. 
The results indicate that students express neutral feelings about the school, although there are differences between the younger and older students and the students with excellent and very good school achievement. The results showed that students also express neutral assessment of learning experience at school, although there are also differences between the younger and older students and the students with excellent and very good school achievement in favour of younger students and high achievers. It was found that students express relatively positive feelings toward relationship with the teachers, although there are differences between younger and older students, students with very good and excellent school achievement and students with very good and lower school achievement. The results indicate that students perceive more positively the quality of social relations with other students, although there are differences between younger and older students, students with excellent and very good school achievement and students with excellent and achievement good and lower school achievement. It was found that students perceive more positively their school competence and that there are gender, grade and school achievement differences in favour of girls, younger students and students with higher school achievement. The analyses of the results indicate that students perceive more positively relevance of schooling, although there are differences between the younger and older students and the students with excellent and very good school achievement.

Positive feelings toward school are an indicator of the students' well-being, i.e. precondition for the development of their emotional and social competencies at school which have important role in their learning motivation and school success. Given result indicate the importance of strengthening the sense of school community, which can contribute to students' perception of the school not only as a place of teaching and acquisition of knowledge, but also as a place, where they like to be and feel happy.

The results of this empirical research, supported by other researchers about the role of quality of school life, indicate that school efficiency should not be reduced exclusively to test results and grades, but rather to the quality of the learning environment in school, which significantly influences the way students learn, how they feel, and how they connect. Research of this subject offers insight into school social environments. The confirmation of strong and weak sides of school life represents the foundation and starting point for introducing sustainable changes to education in terms of improving the quality of schools as places where students learn, experience positive emotions, and build positive social relationships.

\section{References}

Aliyev, R. and Tunc, E. (2015). The Investigation of Primary School Students' Perception of Quality of School Life and Sense of Belonging by Different Variables. Revista de Cercetares $i$ Interventie Sociala, 48, 164-182. 
Ainley, J., Goldman, J. and Reed, R. (1990). Primary Schooling in Victoria: A study of Students' Attitude and Achievements in Years 5 and 6 of Government Primary Schools, ACER Monograph No. 37. Hawthorn, Victoria: Australian Council for Education Research.

Booth, T. and Ainscow, M. (2002). Index for Inclusion, Developing Learning and Participation in Schools, BRISTOL: SCIE.

Diener, E. (2000). Subjective Well-being. The Science of Happiness and a Proposal for a National Index. American Psychologist, 55(1), 34-43.

Epstein, J. L. and McPartland, J. M. (1976). The Concept and Measurement of the Quality of School Life. American Educational Research Journal, 13, 15-30.

Gil, G. A. (1996). Analysis of the Williams and Batten Questionnaire on the Quality of School Life in Spain. In M. Binkley, K. Rust, T. Williams (eds.), Reading Literacy in an International Perspective (pp. 223-239). Washington, DC: U.S. Department of Education, Office of Educational Research and Improvement.

Glauber, H. (2006). Langsamer, Weniger, Besser, Schöner. 15 Jahre Toblacher Gespräche: Bausteine für die Zukunft. München: Oekom Verlag.

Hanzec, I., Kovačević, M. and Brajša-Žganec, A. (2016). Psychosocial Predictors of Students' Academic, Social and Emotional Adjustment at the Beginning of Secondary School. In V. Buško (ed.), Review of Psychology, 23(1-2, pp. 84-85). Jastrebarsko: Naklada Slap.

Hartley, B. L. and Sutton, R. M. (2013). A Stereotype Threat Account of Boys' Academic Underachievement. Child Development, 84, 1716-1733.

Henderson, D. G. and Fisher, D. L. (2008).Interpersonal Behaviour and Student Outcomes in Vocational Education Classes. Learning Environments Research, 11(1), 19-29.

Kaffemanienè, I., Masiliauskienè, E., Melienè, R. and Milteniene், L. (2017). Educational

Environment of the Modern School in the Aspects of Learning Factors, School Climate and Education Paradigms. Pedagogika, 126(2), 62-82.

Karatzias, A., Power, K. G., Flemming, J., Lennan, F. and Swanson, V. (2002). The Role of Demographics, Personality Variables and School Stress on Predicting School Satisfaction/Dissatisfaction: Review of the Literature and Research Findings. Educational Psychology, 22, 33-50.

Kong, C. (2008). Classroom Learning Experiences and Students' Perceptions of Quality of School Life. Learning Environment Research, 11, 111-129.

Leonard, C., Bourke, S. and Schofield, N. J. (1999). Student Stress and Absenteeism in Primary Schools, Paper Presented at the AARE Annual Conference, Melbourne. Retrieved from https://www.aare.edu.au/data/publications/1999/leo99542.pdf

Leonard, C., Bourke, S. and Schofield, N. (2000).Quality of School Life and Absenteeism in Primary Schools, Paper Presented at the AARE Annual Conference, 4-7 December 2000 - Sydney. Retrieved from https://www.aare.edu.au/data/publications/2000/leo00214.pdf Leonard, C., (2002). Quality of School Life and Attendance in Primary School (Doctoral Thesis). Retrieved from http://nova.newcastle.edu.au/vital/access/manager/Repository/uon:687 Linnakylä, P. and Brunell, V. (1996.). Quality of School Life in the Finnish and Swedish-Speaking Schools in Finland. In M. Binkley, K. Rust and T. Williams (eds.), Reading Literacy in an 
International Perspective (pp. 203-217). Washington, U.S. Department of Education, Office of Educational Research and Improvement.

Malin, L. A. and Linnakyla, P. (2001). Multilevel Modelling in Repeated Measures of the Quality of Finnish School Life. Scandinavian Journal of Educational Research, 45(2), 145-166.

Marks, G. (1998). Attitudes to School Life: Their Influences and Their Effects on Achievement and Leaving School. LSAY Research Reports. Longitudinal Surveys of Australian Youth Research Report; n.5, Retrieved fromhttp://research.acer.edu.au/lsay_research/62

Meriläinen, M., Lappalainen K. and Kuittinen, M. (2008). Pedagogiikan ja Hyvinvoinnin Suhde. In K. Lappalainen, M. Kuittinen and M. Meriläinen (eds.), Pedagoginen Hyvinvointi (pp. 7-14). Turku: Painosalama OY.

Mok, M. and Flynn, M. (1997). Does School Size Affect Quality of School Life? Issues in Educational Research, 7(1), 69-86.

Okun, M. A., Walton-Braver, M. and Weir, R. M. (1990). Grade level differences in school satisfaction. Social Indicators Research, 22, 419-427.

Pang, N. S. (1999a). Students' Quality of School Life in Band 5 Schools. Asian Journal of Counselling, 6, 79-105.

Pang, N. S. (1999b). Students' Perceptions of Quality of School Life in Hong Kong Primary Schools. Education Research Journal, 14(1), 49-70.

Pietarinen, J., Soini, T. and Pyhältö, K. (2008). Pedagoginen Hyvinvointi-uuttaja Tuttua Koulun Arjesta. In K. Lappalainen, M. Kuittinen, M. Meriläinen (EDS.), Pedagoginen Hyvinvointi (pp. 53-74). Turku: Painosalama OY.

Pomerantz, E. M., Altermatt, E. R. and Saxon, J. L. (2002). Making the Grade but Feeling Distressed: Gender Differences in Academic Performance and Internal Distress. Journal of Educational Psychology, 94(2), 396-404.

Raboteg-Šarić, Z. and Šakić, M. (2007). Quality of School Life, Self-regulated Learning and Academic Achievement. Abstracts-13th European Conference on Developmental Psychology. Jena: European Society for Developmental Psychology and Centre for Applied Developmental Science.

Raboteg-Šarić, Z. Šakić, M. and Brajša-Žganec, A. (2009). Kvaliteta života u osnovnoj školi: povezanost sa školskim uspjehom, motivacijom i ponašanjem učenika. Društvena istraživanja, 4-5(102-103), 697-716.

Rifkin, J. (2006). Europski san: kako europska vizija budućnosti polako zasjenjuje američki san, Zagreb: Školska knjiga.

UNESCO (2005). Education for All - The Quality Imperative. Paris: EFA Global Monitoring Report, UNESCO publishing. Paris, France.

Vojtová, V. (2008). Quality of School Life from the Pupils' Perspective; research thesis. In O. Řehulková, E. Řehulka, M. Blatný and J. Mareš (eds.), Quality of life in the context of health and illness (pp. 78-89). Brno: Masarykova Univerzita.

Wolf, F. M., Chandler, T. A. and Spies, C. J. (1981.). A Cross-lagged Panel Analysis of Quality of School Life and Achievement Responsibility. Journal of Educational Research, 74, 363-368. 


\title{
Mokyklinio gyvenimo kokybė pagrindinèje mokykloje: mokinių suvokimas
}

\author{
Marija Buterin Mičić
}

Zadaro universitetas, Pedagogikos katedra, Obala kralja Petra Krešimira IV. 2, HR-23000, Zadaras, Kroatija, mbuterin2@gmail.com

\section{Santrauka}

Svarstymai apie neakademinio ugdymo svarbą dažnai skatina diskusijas apie mokinių išgyvenimų ir jausmų, susijusių su įvairiais mokyklos gyvenimo aspektais, kokybę. Šio tyrimo tikslas - ịvertinti mokinių suvokimą apie mokyklinio gyvenimo kokybę. Mokinių duomenys buvo renkami ir analizuojami pagal lytị, klasę ir pasiekimus mokykloje. Tyrimo imtị sudarè 433 penktų - aštuntų klasių mokiniai. Duomenys buvo surinkti atliekant anketinę apklausą raštu. Nustatyta, kad mokiniai pateikia neutralų savo suvokimo apie mokymąsi mokykloje, kaip apie sudètingą ir malonų procesą, vertinimą, tačiau palyginti teigiamai vertina kitus specifinius mokyklinio gyvenimo aspektus (mokymosi aktualumą; savitarpio santykius su mokytoju, mokiniais ir kitais žmonėmis mokykloje; mokyklinès kompetencijos svarbą). Mokyklinio gyvenimo kokybės vertinimo skirtumai analizuoti atsižvelgiant ị mokinių lytį, klasę ir pasiekimus mokykloje. Nustatyta, kad mergaitės statistiškai reikšmingai palankiau vertina mokyklinès kompetencijos svarbą nei berniukai. Be to, mergaitėms geriau sekasi mokyklinèse veiklose. Nustatyti statistiškai reikšmingi skirtumai tarp bendro pasitenkinimo mokykla ir suvokimo apie specifinius mokyklinio gyvenimo aspektus, atsižvelgiant ị klasę ir pasiekimus mokykloje, kuriuos labiau teigiamai vertina jaunesniųjų klasių moksleiviai bei mokiniai, turintys geresnių mokyklinių pasiekimų.

Esminiai žodžiai: mokiniai, mokyklinis gyvenimas, pagrindinė mokykla, mokinių suvokimas. 